\title{
FLUX-CORED STRIPS FOR WEAR-RESISTANT SURFACING
}

\author{
A.P. VORONCHUK \\ E.O. Paton Electric Welding Institute, NASU \\ 11 Bozhenko Str., 03680, Kiev, Ukraine. E-mail: office@paton.kiev.ua
}

\begin{abstract}
Advantages of flux-cored strip application as electrode material for wear-resistant surfacing are considered. The list of batch-produced flux-cored strips, their typesizes and form of delivery is given. Examples of techniques of strip application for surfacing cones and cups of blast furnace charging equipment, pans of coneless charging devices, beaters of coal-pulverizing mills, cutters for hot cutting of metal, and production of wear-resistant bimetal sheets are presented. Kinds of new specialized equipment for surfacing with flux-cored strips are shown, namely A1812M apparatus for surfacing cones and cups of blast furnace charging equipment, AD 380.03 unit for plate surfacing, UD298M unit for surfacing cutters for hot cutting of metal. All the equipment is fitted with control systems based on microcontrollers. Enterprises, where new developments have been introduced, are listed. 8 Ref., 1 Table, 6 Figures.
\end{abstract}

Keywords : flux-cored wire, compositions, surfacing, equipment, technology, surfacing efficiency, application

Hardfacing is an effective method of increasing wear resistance and serviceability of parts of machines exposed to intensive abrasive wear. A large range of parts are surfaced during manufacture, and reconditioning surfacing is also used.

Alloys of the type of high-chromium cast irons with a high degree of alloying of up to $40 \%$ and higher became widely accepted for strengthening various parts, operating under the conditions of intensive abrasive and gas-abrasive wear. For these purposes leading European companies such as Castolin (Sweden), Buller (Switzerland), Durum (Germany), Welding Alloys (Great Britain) and others offer flux-cored wires made by rolling in specialized mills. Manufacturing flux-cored wires with filling coefficient above $40 \%$ by drawing method, which is widely used in Ukraine and other CIS countries, is very difficult. Therefore, this problem could be much simpler solved by

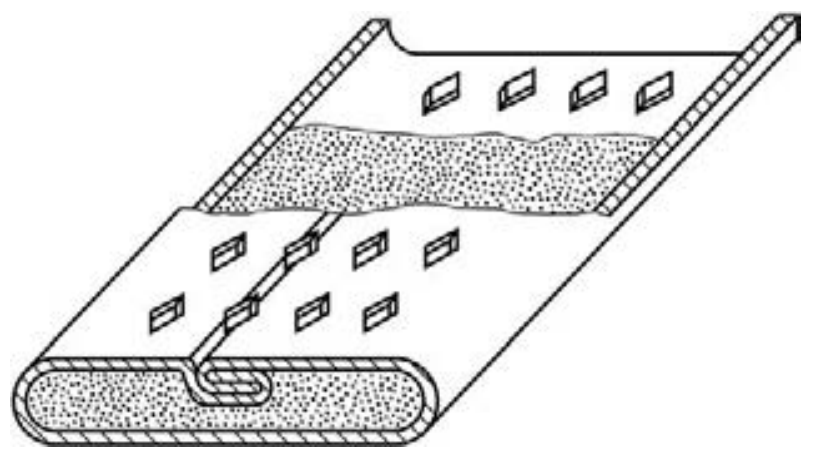

Figure 1. Design of single-lock flux-cored strip with tight lock joint

() A.P. VORONCHUK, 2014 development of similar compositions of fluxcored wire strips. This surfacing material readily allows achieving filling coefficients up to 60$70 \%$, and its manufacturing technology excludes the drawing process.

At present flux-cored strip is a well-known surfacing material, which is widely applied for manufacture and strengthening of a wide range of parts in metallurgical, power, mining, roadconstruction and other industries. Unlike fluxcored wire the main advantage of flux-cored strips is high deposition rate.

At present annual production volume of fluxcored strips in CIS countries is equal to about $600 \mathrm{t}$ and has a stable growth tendency.

Flux-cored strip, the design of which is shown in Figure 1, has become the most widely accepted in industry [1, 2]. Currently available equipment allows manufacturing two typesizes of material of $16.5 \times 4$ and $10 \times 3 \mathrm{~mm}$ section. Flux-cored strip is supplied in bundles of $80-160 \mathrm{~kg}$ weight with row-by-row laying. Bundle inner diameter is $400-460 \mathrm{~mm}$, outer diameter is up to $850 \mathrm{~mm}$ and width is $115-130 \mathrm{~mm}$. Reliable sealing of flux-cored strip lock joint, its supply in bundles of large weight ensure continuous high-efficient surfacing that is particularly important at strengthening of large-sized parts with large working surfaces.

Surfacing with flux-cored strips is performed both by an open arc and by submerged arc. The process of submerged-arc surfacing by flux-cored strip practically does not differ from submergedarc welding by other electrode materials.

Flux-cored strip typesize, surfacing modes and its schematics are selected depending on typesize 
Flux-cored strips for surfacing

\begin{tabular}{|c|c|c|c|c|c|c|c|c|c|c|c|c|c|}
\hline \multirow{2}{*}{$\begin{array}{l}\text { Flux-cored strip } \\
\text { grade }\end{array}$} & \multicolumn{11}{|c|}{ Deposited metal composition, wt.\% } & \multirow{2}{*}{$\begin{array}{l}\text { Hardness } \\
H R C\end{array}$} & \multirow{2}{*}{ Purpose } \\
\hline & $\mathrm{C}$ & $\mathrm{Cr}$ & $\mathrm{Mn}$ & $\mathrm{Si}$ & $\mathrm{Ni}$ & $\mathrm{Nb}$ & Mo & $\mathrm{V}$ & $\mathrm{W}$ & $\mathrm{B}$ & $\mathrm{Ti}$ & & \\
\hline $\begin{array}{l}\text { PL-AN-101 } \\
\text { PL-AN-171 } \\
\text { PL-AN-180 } \\
\text { PL-AN-181 }\end{array}$ & $\begin{array}{l}3.0 \\
1.2 \\
4.5 \\
4.5\end{array}$ & $\begin{array}{l}25 \\
25 \\
30 \\
30\end{array}$ & $\begin{array}{c}2.0 \\
2.2 \\
- \\
3.0\end{array}$ & $\begin{array}{c}3.0 \\
1.0 \\
- \\
-\end{array}$ & $\begin{array}{c}2.0 \\
- \\
- \\
-\end{array}$ & $\begin{array}{l}- \\
- \\
- \\
-\end{array}$ & $\begin{array}{c}- \\
- \\
1.0 \\
-\end{array}$ & $\begin{array}{l}- \\
- \\
- \\
-\end{array}$ & $\begin{array}{l}- \\
- \\
- \\
-\end{array}$ & $\begin{array}{c}- \\
3.5 \\
- \\
-\end{array}$ & $\begin{array}{l}- \\
- \\
- \\
-\end{array}$ & $\begin{array}{l}50-56 \\
54-59 \\
58-62 \\
58-60\end{array}$ & $\begin{array}{l}\text { Surfacing of parts, exposed to } \\
\text { abrasive wear in service } \\
\text { (bulldozer and gripper jaws, } \\
\text { excavator bucket teeth, coke } \\
\text { crusher rolls, plough disks, } \\
\text { protective surfaces of cones, } \\
\text { cups, etc.) }\end{array}$ \\
\hline $\begin{array}{l}\text { PL-AN-111 } \\
\text { PL-AN-179 } \\
\text { PL-AN-185 } \\
\text { PL-AN-186 }\end{array}$ & $\begin{array}{l}5.0 \\
5.0 \\
5.0 \\
4.5\end{array}$ & $\begin{array}{l}38 \\
22 \\
22 \\
30\end{array}$ & $\begin{array}{c}1.0 \\
- \\
- \\
-\end{array}$ & $\begin{array}{c}2.5 \\
- \\
- \\
-\end{array}$ & $\begin{array}{c}38.0 \\
- \\
- \\
-\end{array}$ & $\begin{array}{c}- \\
7.0 \\
7.0 \\
-\end{array}$ & $\begin{array}{c}- \\
6.0 \\
- \\
-\end{array}$ & $\begin{array}{l}- \\
1.0 \\
- \\
-\end{array}$ & $\begin{array}{c}- \\
2.0 \\
- \\
-\end{array}$ & $\begin{array}{c}0.3 \\
- \\
- \\
0.7\end{array}$ & $\begin{array}{l}- \\
- \\
- \\
-\end{array}$ & $\begin{array}{l}50-58 \\
58-62 \\
56-60 \\
57-62\end{array}$ & $\begin{array}{l}\text { Surfacing of parts, exposed to } \\
\text { intensive abrasive and gas- } \\
\text { abrasive kinds of wear at } \\
\text { normal and elevated } \\
\text { temperatures (cones and cups of } \\
\text { blast furnace charging } \\
\text { equipment, chutes, hoppers, } \\
\text { etc.) }\end{array}$ \\
\hline $\begin{array}{l}\text { PL-AN-132-1 } \\
\text { PL-AN-132-2 } \\
\text { PL-AN-132-3 }\end{array}$ & $\begin{array}{c}0.1 \\
0.15 \\
0.2\end{array}$ & $\begin{array}{l}4 \\
4 \\
4\end{array}$ & $\begin{array}{l}1.5 \\
1.5 \\
1.5\end{array}$ & $\begin{array}{l}1.0 \\
1.0 \\
1.0\end{array}$ & $\begin{array}{l}- \\
- \\
-\end{array}$ & $\begin{array}{l}- \\
- \\
-\end{array}$ & $\begin{array}{l}2.0 \\
2.0 \\
2.0\end{array}$ & $\begin{array}{l}- \\
- \\
-\end{array}$ & $\begin{array}{l}2.5 \\
2.5 \\
2.5\end{array}$ & $\begin{array}{l}- \\
- \\
-\end{array}$ & $\begin{array}{l}- \\
- \\
-\end{array}$ & $\begin{array}{l}18-28 \\
28-34 \\
35-45\end{array}$ & $\begin{array}{l}\text { Surfacing of parts exposed to } \\
\text { contact loads at elevated } \\
\text { temperature (roller conveyor } \\
\text { rollers, rolls, etc.) }\end{array}$ \\
\hline PL-AN-187 & 0.2 & 11 & 10.0 & - & - & - & - & - & - & - & 0.8 & $18-26$ & $\begin{array}{l}\text { Surfacing of parts exposed to } \\
\text { high contact loads in service } \\
\text { (crane wheels, guides, etc.) }\end{array}$ \\
\hline PL-AN-115 & 0.1 & - & 1.5 & 0.8 & - & - & - & - & - & - & 0.5 & $18-26$ & $\begin{array}{l}\text { Surfacing of large-sized steel } \\
\text { parts to restore their } \\
\text { geometrical dimensions (cones } \\
\text { and cups of blast furnace } \\
\text { charging equipment, } \\
\text { agglomachine trucks, etc.) }\end{array}$ \\
\hline $\begin{array}{l}\text { PL-AN-189 } \\
\text { PL-AN-190 } \\
\text { PL-AN-191 }\end{array}$ & $\begin{array}{c}0.35 \\
0.4 \\
0.25\end{array}$ & $\begin{array}{l}3 \\
3 \\
5\end{array}$ & $\begin{array}{l}0.8 \\
0.8 \\
0.7\end{array}$ & $\begin{array}{l}0.6 \\
0.6 \\
1.0\end{array}$ & $\begin{array}{l}- \\
- \\
-\end{array}$ & $\begin{array}{l}- \\
- \\
-\end{array}$ & $\begin{array}{c}- \\
- \\
1.2\end{array}$ & $\begin{array}{l}0.3 \\
0.3 \\
0.4\end{array}$ & $\begin{array}{c}9.0 \\
9.0 \\
-\end{array}$ & $\begin{array}{l}- \\
- \\
-\end{array}$ & $\begin{array}{l}- \\
- \\
-\end{array}$ & $\begin{array}{l}44-50 \\
44-50 \\
46-52\end{array}$ & $\begin{array}{l}\text { Surfacing of rolls for hot rolling } \\
\text { of metal }\end{array}$ \\
\hline PL-AN-183 & 0.4 & 2 & 1.6 & 1.6 & 5.5 & 0.6 & 1.8 & 0.5 & - & - & - & $47-54$ & $\begin{array}{l}\text { Surfacing of blades for hot } \\
\text { cutting of metal }\end{array}$ \\
\hline $\begin{array}{l}\text { PL-AN-150 } \\
\text { PL-AN-151 }\end{array}$ & $\begin{array}{l}0.12 \\
0.12\end{array}$ & $\begin{array}{l}16 \\
16\end{array}$ & $\begin{array}{l}2.0 \\
4.0\end{array}$ & $\begin{array}{l}5.0 \\
5.0\end{array}$ & $\begin{array}{l}9.0 \\
8.0\end{array}$ & $\begin{array}{c}- \\
1.0\end{array}$ & $\frac{-}{6.0}$ & - & - & - & - & $\begin{array}{l}27-34 \\
38-50\end{array}$ & $\begin{array}{l}\text { Submerged-arc surfacing of } \\
\text { fittings operating at up to } \\
545^{\circ} \mathrm{C} \text { ambient temperature }\end{array}$ \\
\hline
\end{tabular}

of the part being strengthened. Surfacing can be performed in one, two and more layers; by isolated beads and in wide layers, with oscillation range from 50 up to $400 \mathrm{~mm}$. Surfacing currents here can be varied from 300 up to $1200 \mathrm{~A}$, arc voltage - from 25 up to $38 \mathrm{~V}$, electrode displacement rate - from 5 up to $100 \mathrm{~m} / \mathrm{h}$. Twin and multiarc surfacing is applied to increase the efficiency, that is provided by specially developed equipment. Wear-resistant layer of 2 to $8 \mathrm{~mm}$ thickness can be deposited in one pass by one arc, and surfacing efficiency reaches 25$30 \mathrm{~kg}$ of deposited metal per hour.

Flux-cored strip consumption when recalculated per $1 \mathrm{~kg}$ of deposited metal is equal to $1.1-1.2 \mathrm{~kg}$ in the presence of volatile components in the powder filler and $1.20-1.35 \mathrm{~kg}$ in the presence of mineral components [2].
For surfacing with flux-cored strips, batchproduced welding equipment is additionally fitted with special nozzles and feed rollers, providing reliable electrode material feed. AD 231 unit is most often used.

The Table gives flux-cored strip grades, which have been mastered and are batch-produced by industry.

Flux-cored strip advantages are the most fully realized in surfacing of batch-produced parts. In this case, original technologies with application of specialized equipment are used for strengthening.

A traditional example of application of fluxcored strip for strengthening parts for metallurgical production is surfacing of blast furnace charging equipment. Unique units U-50, U-75 and U-125 have been developed for these pur- 


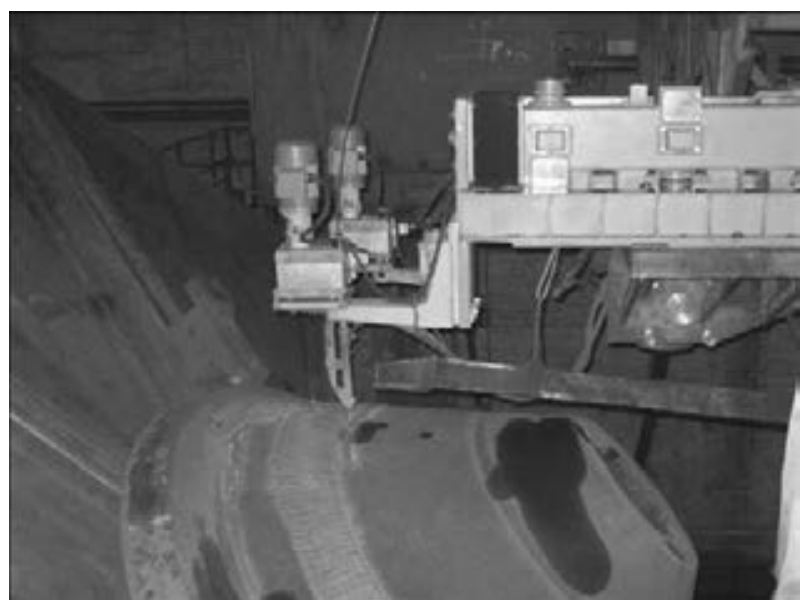

Figure 2. A1812M unit

poses [2-4]. Starting from 2002, the units are fitted with new upgraded surfacing apparatus A1812M (Figure 2), and control system of SU 320 type [5]. The apparatus ensures surfacing by two tandem or parallel arcs, as well as transverse oscillations of the electrode with 50 to $500 \mathrm{~mm}$ amplitude. Unit design also envisages surfacing performance around a circle and open-arc and submerged-arc welding of large-sized parts with flux-cored and solid-drawn wires. Unit control system is based on a microcontroller, and units are fitted with asynchronous AC motors with frequency converters.

Mechanized surfacing of cones and cups with self-shielded flux-cored wires is 4 times more efficient than the process of flux-cored wire surfacing.

New apparatuses and control systems have been introduced with success in OJSCs «Mittal Steel Krivoy Rog», Ukraine), «Azovmash» (Mariupol, Ukraine) and ZSMK (Novokuznetsk, RF).

One of the examples of comprehensive solution of strengthening problems is surfacing of 5 to $20 \mathrm{~mm}$ plates [6, 7]. Specialized surfacing unit AD 380.03 is used for these purposes [8]. It con-

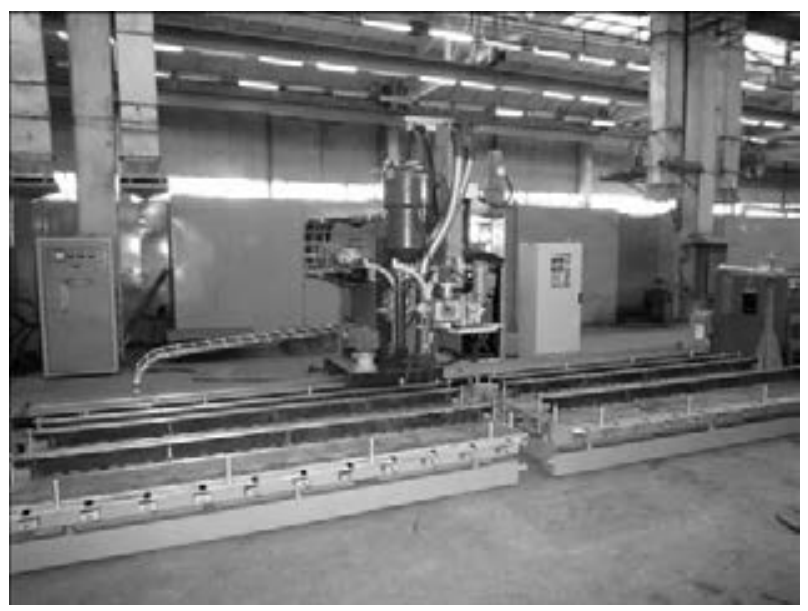

Figure 3. General view of AD 380.03 unit

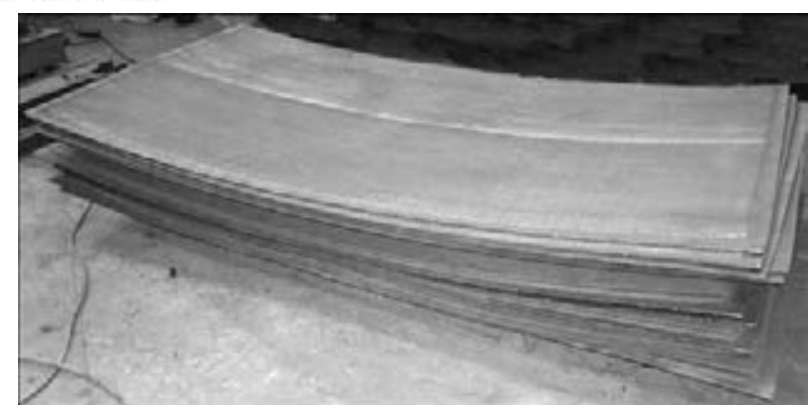

Figure 4. Bimetal sheets after surfacing

sists of a carriage with two surfacing heads, moving along a guide, and two tables for fastening $3000 \times 1500 \mathrm{~mm}$ steel plates. The carriage can move with working and travel speed. The unit is fitted with two power sources with a flat external characteristic.

Self-shielded flux-cored strip ensuring deposited metal of the $4.5 \mathrm{Cr}, 30 \mathrm{Cr}$, $1 \mathrm{Mo}$ composition (wt.\%) is used as electrode material. Deposited layer hardness is $H R C 60$.

Flux-cored strip of $10 \times 3 \mathrm{~mm}$ cross-section is used for surfacing 5 to $7 \mathrm{~mm}$ sheets, and strip of $16.5 \times 4.0 \mathrm{~mm}$ cross-section is applied for $8 \mathrm{~mm}$ and thicker plates.

The unit is controlled by electric circuit based on a microcontroller, which allows sheet surfacing to be performed by two programs.

The unit allows surfacing to be performed in the automatic mode by the developed program on two tables alternatively with the efficiency of 1 sheet of $3000 \times 1500 \mathrm{~mm}$ size per work shift at twin-arc surfacing.

The unit for sheet surfacing and the strengthened sheet are shown in Figures 3 and 4. Another example of wide application of flux-cored strip for wear-resistant surfacing is the process of

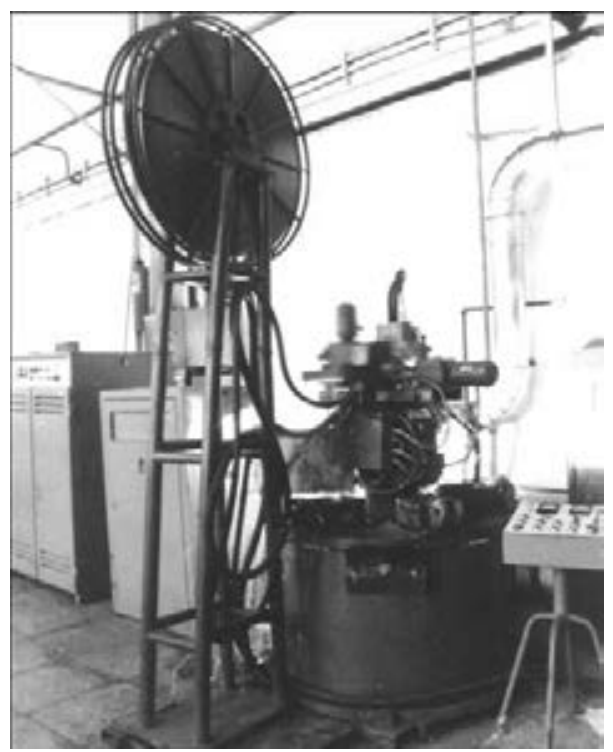

Figure 5. U-877 unit 
strengthening of coal-crushing mill beaters [2, $3]$. Beater surfacing is performed in specialized units U-877 (Figure 5), consisting of surfacing system, rotating table and five water-cooled iron moulds mounted on it, into which beaters to be surfaced are placed. Beater surfacing is performed in the automatic mode with electrode oscillations across the entire width of the part being surfaced. One unit allows surfacing 100120 beaters per shift.

Surfacing of low-carbon steel cast billets is performed with PL-AN-101 flux-cored strip, which allows producing a deposited layer of the following composition, wt.\%: $3 \mathrm{C}, 25 \mathrm{Cr}, 3 \mathrm{Si}, 2 \mathrm{Ni}$,

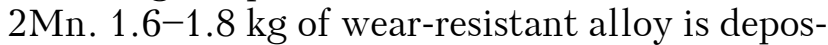
ited on one beater. Application of this technology and electrode material in the form of flux-cored strip allowed extending service life of strengthened parts 2 times, compared to earlier applied all-cast beaters from Hadfield steel.

Positive results were obtained also, when strengthening parts of coneless charging equipment of blast furnaces using flux-cored strip. We developed the technology of surfacing fast-wearing parts of the pan and other elements of the structure of charging equipment of «PaulWurth» company (Luxembourg).

Technology and UD298M unit (Figure 6) were developed for flux-cored strip open-arc surfacing of cutters for hot cutting of metal, which allows strengthening cutter working edges in the automatic mode [2]. Here, efficiency of surfacing process increases rapidly. Flux-cored strip PLAN-183 was developed as surfacing material. Its application markedly, by 1.5 to 2 times, increases the resistance of strengthened parts compared to those surfaced with flux-cored wire $\mathrm{PP}-\mathrm{Np}$ 35V9Kh3SF. Here, the efficiency of surfacing process rose 2 to 3 times.

Flux-cored strips became widely accepted also at strengthening of a wide range of components for mining equipment. This electrode material is also used for strengthening bulldozer blades, cone crusher lining, grinding fan blades and many

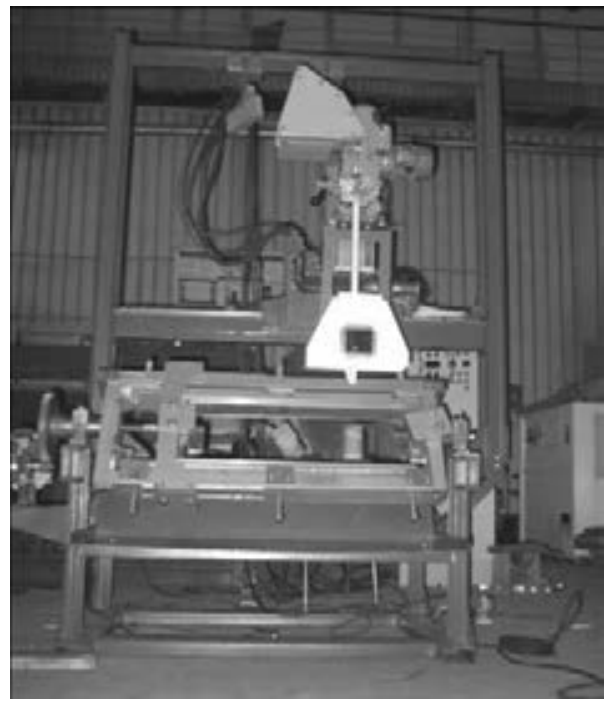

Figure 6. UD298M unit

other components exposed to intensive abrasive wear and other kinds of wear in service.

1. Danilchenko, B.V., Shimanovsky, V.P., Kopylets, I.P. et al. Flux-cored strip electrode. USSR author's cert. 1152159. Int. Cl. B $23 \mathrm{~K} 35 / 40$. Publ. 22.12 .1984

2. Zhudra, A.P., Voronchuk, A.P. (2012) Cladding flux-cored strips (Review). The Paton Welding J., 1, 34-38.

3. Shimanovsky, V.P., Voronchuk, A.P., Zvezdin, S.M. (1990) Consumables and equipment for hard-facing of blast furnace cones and cups. In: Equipment and consumables for surfacing: Transact. Kiev: PWI, 71-73.

4. Danilchenko, B.V., Shimanovsky, V.P., Voronchuk, A.P. et al. (1989) Hard-facing of rapidly wearing parts with self-shielded flux-cored strips. Avtomatich. Svarka, 5, 38-41.

5. Zhudra, A.P., Voronchuk, A.P., Fomakin, A.A. et al. (2009) New equipment for hard-facing of charging device bells and cups. The Paton Welding J., 9, 44-46.

6. Zhudra, A.P., Voronchuk, A.P. (2010) Wear-resistant flux-cored strip hard-facing. Svarshchik, 6, $6-10$.

7. Zhudra, A.P., Voronchuk, A.P., Kochura, V.O. et al. (2012) Technology, equipment and consumables for production of sheet lining elements. Svarochn. Proizvodstvo, 11, 40-43.

8. Zhudra, A.P., Voronchuk, A.P., Veliky, S.I. (2009) Equipment and consumables for hard-facing of lining plate elements. The Paton Welding J., 6, 44-46.

Received 02.04.2014 